\title{
Economic impacts of ponds management on water quality and growth performance of fish in polyculture
}

\author{
Ibrahim M. Shaker ${ }^{1}$; Mohamed Y. Abou Zead ${ }^{2}$ and Alam EI Deen Farouk ${ }^{1}$ \\ 1- Central Laboratory for Aquaculture Research, Agriculture Research Center, \\ Ministry of Agriculture, Egypt. \\ 2- World Fish., AbouHammad, Sharkia, Egypt. \\ Corresponding author: dr_ibrahim_shaker@yahoo.com
}

\section{ABSTRACT}

The present study was conducted to evaluate the economics of the fish farms management under different systems and different water sources and its impact on the growth performance of fish in polyculture. The study was conducted in two fish farms in the provinces of Kafr El-Sheikh, Ismailia and Port Said, four earthen ponds in each fish farm two feddans for each pond. The ponds were cultivated by Nile tilapia and mullet with an average weight of 2; $30 \mathrm{~g}$ for tilapia and mullet, respectively. The first fish farm was fertilized by organic and mineral fertilizers only during the first three months and then the artificial feed was added until harvest. In the second fish farm used in artificial feed $25 \%$ Protein only during the whole season. Water samples were taken monthly to measure water quality parameters and phytoplankton and zooplankton abundance. Also, fish samples were taken monthly to calculate growth rates.

Significantly increase in nitrogen compounds $\left(\mathrm{NH}_{4}, \mathrm{NH}_{3}, \mathrm{NO}_{2}, \mathrm{NO}_{3}\right)$, dissolved phosphorus and chlorophyll "a" in the fertilization fish farms led to increased phytoplankton and zooplankton.

The results revealed significant increase in tilapia survival rate than mullet and significant increase in daily growth rate in tilapia than mullet in each fish pond under different pond managements. The daily growth rate significantly increased in feed system ponds than fertilizers system. Significantly increase of total fish production per Fadden on Shader Azzam and after Kafr El-Sheikh fish ponds in each pond managements. Significantly increase of total fish production per Fadden on Shader Azzam and after the Kafr el-Sheikh fish ponds under feeding systems and the same trends in fertilizers systems.

Significantly increase Dabbashi, Super, Grad1 in tilapia production in feed systems than fertilizers. The cost of feed per feddan were 44.99, 79.4, 44.65, 78.78, 45.97 and $76.53 \%$ of total operating costs in KM; KF; IF; IM; PM and PF fish farm respectively. The total returns of fish were 22780, 40930, 23630, 39030, 22730 and 35930L.E in the same fish farms respectively. The study indicated that fertilization reduces the cost of production, but artificial feed must be used with fertilization in the last two months of the season.

Keywords: Polyculture, Fertilizers, artificial feed, pond management, water quality, phytoplankton, zooplankton.

\section{INTRODUCTION}

Increasing the cost of fish feeds and inorganic fertilizers results in increasing the interest in lowering the cost of fish production and this can be solved, to some extent by introducing an integrated farming system (Shaker, 2008). 
The polyculture as practiced in aquaculture via stocking of fish species of different food habits proved to be an important management tool in utilizing efficiently the natural food resources in fish pond. Synergistic interactions among fish species are manifested by higher growth and yield in polyculture than in monoculture. The bases for these interactions are the increase of available food resources and the improvement of environmental conditions (Shaker et al., 2013).

Polyculture was first practiced in China more than a thousand years ago. It was extremely extensive, requiring little management, stocking several species at low density, often without application of feeds, and producing relatively low yield at low production costs (Afzal, et al., 2007). In semi-intensive farming systems, usually natural food is stimulated through the application of organic manures or chemical fertilizers, while feeds are supplied to supplement the available natural food.

Fertilizers are applied for fertilization of fish ponds to increase plant nutrients contraction and to stimulate natural fish growth and ultimately increase fish production. Availability of natural food in pond water reduces fish demand for artificial feeds, leading to reduce production costs and improve farm income. Chicken manure has been used extensively as organic fertilizers in fish farms for increasing natural food web and consequently reducing production costs. Chemical fertilizers are highly soluble and release nutrients that can cause eutrophication of natural waters.

Recently, along with the intensification trend in Egyptian aquaculture, the requirement for high quality feed has increased. Such higher production costs as well as the high investments have called for better management practices. The contribution of feed costs in fish production increases along with the level of intensification, reaching the highest component in farm operation (Shaker, and Abd El Aal, 2006). From economic point of view, such practices may not suite the small-scale farmers with little resources whether in the tropics and to some extent in some parts of Egypt. This is due to financial constraints which limit the ability of those farmers from accessing the commercially produced pelleted feeds. Thus, in order for those farms to utilize easy to find feed at low cost, alternative management strategies are required.

Anumber of studies have been done on feed and fertilizer combinations, which may be very effective, where fertilization rates can be reduced due to enrichment gained from excreta and exhibited rapid growth rate of tilapia, since larger size could be attained in shorter time than fertilizer alone and also the production cost may be reduced (Eroldogan et al., 2006 and Abdel-Hakim et al., 2009). Fish feed prices have increased significantly during the last few years which reduced the profit margin of fish farming and caused losses in some farms. As a direct result of that farming net profits declined and most of the business has changed their production plan depending more on fertilizers. Therefore, the objectives of the present study are to evaluate fish production and growth performance as well as the grow-out environments under different pond managements of fish cultured. Economical evaluation for farming systems tested was a main element in the study. Finally, the study tackled the issue of the use of drainage water, sewage wastewater and fresh water in Egyptian fish farming.

\section{MATRIALS AND METHODS}

The study was conducted in Kafr El-Sheikh-Ismailia and Port Said governorates, two fish farms for each.The fish farms in Kafr El-Sheikh (KM, KF) are irrigated from agriculture drainage water beside and water from Lake Burullus, in Ismailia fish farms (TM, TF) located from El Tal El Kabeer are irrigated from 
Ismailia Canal and in Port Said (PM, PF) located in ShaderAzam are irrigated from Hadous, Ramsise, Baher El Bakar drains and Lake Manzala. The two fish farms in each governorate divided two systems of pond management. First fish farm feed only and second fish farm use organic and mineral fertilizers system and in last month use artificial feed $25 \%$ protein as $2-3 \%$ of total weight of fish twice daily, six days/ week. The feed fish farms are using artificial feed $25 \%$ protein as $3 \%$ of total weight of fish twice daily, five days/week. The fertilizer fish farm use $(50 \mathrm{~kg}$ chicken manure $+4 \mathrm{~kg}$ urea+10kg triple superphosphate/feddan /week) during first four months and in last month using artificial feed $25 \%$ in each governorate.Each fish farm (earthen ponds) four replicates, $8000 \mathrm{~m}^{2}$ for each pond surface area. All ponds had $1.25 \mathrm{~m}$ as an average water depth. Each pond cultivated by 16000 tilapia $2 \mathrm{~g}$ and 4000 mullet $30 \mathrm{~g}$. The experimental period was 150days.

Water temperature ${ }^{\circ} \mathrm{C}$, dissolved oxygen $\mathrm{DO} \mathrm{mg} / \mathrm{l}, \mathrm{pH}$, salinity, electrical conductivity, total ammonia $\mathrm{NH}_{4}, \mathrm{SD}$, total alkalinity $(\mathrm{mg} / \mathrm{l})$, total hardness, nitrite $(\mathrm{mg} / \mathrm{l})$, nitrate $(\mathrm{mg} / \mathrm{l})$, orthophosphate $(\mathrm{mg} / \mathrm{l})$ and chlorophyll "a" $(\mu \mathrm{g} / \mathrm{l})$ were determined according to (APHA, 2000).

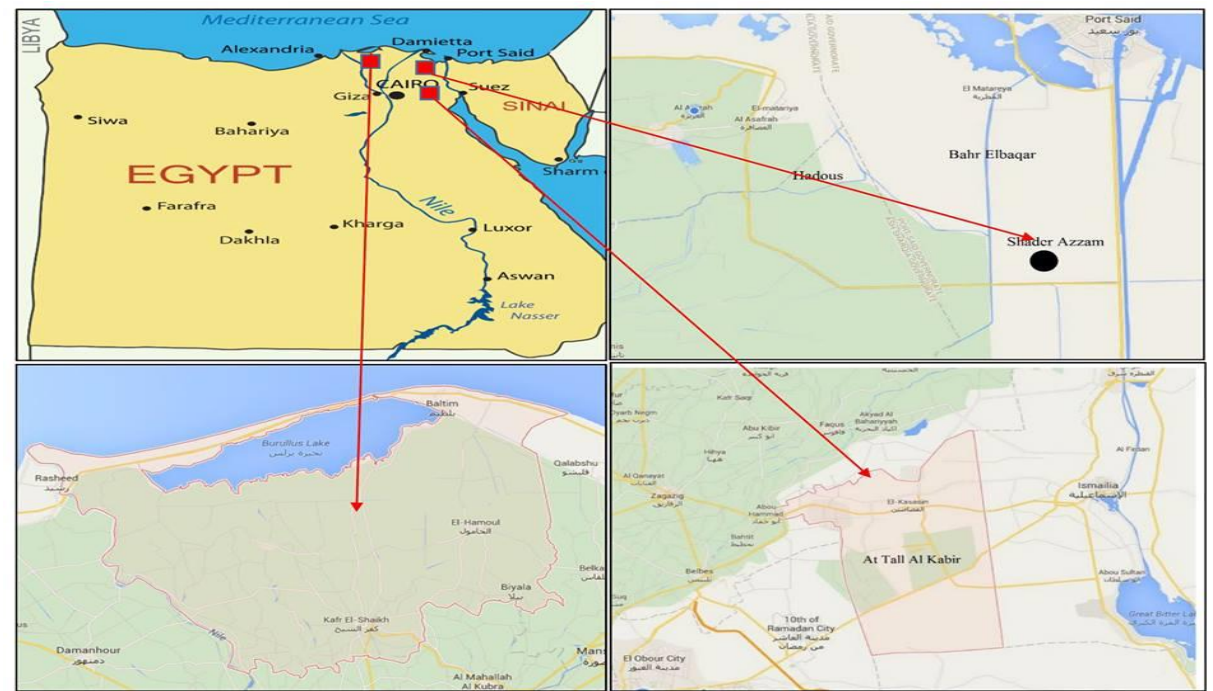

Fig.1: A map of Egypt showing of different fish farms in Kafr El-Sheikh; El Tal El Kabeer in Ismailia and ShaderAzam in Port Saied governorates.

Quantitative and qualitative estimation of phytoplankton and zooplankton standing crop was performed monthly in all ponds during the experimental period. Phytoplankton and zooplankton standing crop was estimated by sedimentation method described in APHA (2000).

During the study period, tilapia and mullet samples were taken monthly to measure weight and length of fish to calculate the growth rate and adjust the amount of feed and returned fish to theponds again.Specific growth rate was estimated as: SGR ln (final weight) -ln (initial weight) /culture period daysX100.

Statistical analyses:

Two-way ANOVA was used to evaluate the significant difference of the concentration of different items studied with respect to fish farms and pond managements. A probability at level of 0.05 or less was considered significant. Standard errors were also estimated. All statistics were run on the computer, using the SAS programme (SAS, 2000). 


\section{RESULTS AND DISSCISIONS}

Water is a major component and physiological necessity of all living things; in addition, aquatic species live in water. An adequate volume of high quality water is necessary to initially fill holding and culture units at aquaculture facilities, and to replace water that evaporates, seeps, or is intentionally discharged from them (Boyd and McNevin, 2015).

The monthly fluctuated of $\mathrm{pH}, \mathrm{SD}, \mathrm{NH}_{3}, \mathrm{NO}_{2}, \mathrm{NO}_{3}$, orthophosphate and chlorophyll "a" parameters presented in figs (2). The average values of DO had negative correlation with experiment period. The concentration of dissolved oxygen gradually decreases from month to month, and it is probably due to the increase of biomass per meter and also to increase the organic matter due to increased waste and residues.

The average values of $\mathrm{pH}$ were slowly differ from month to month in feed ponds regardless fish farms, while were significantly $(\mathrm{P}<0.05)$ increase with period in fertilizers fish ponds in three fish farms. These results indicated that the $\mathrm{pH}$ values had affected by fertilizers. Also, these results clear that the artificial feed were not effect on water $\mathrm{pH}$. The fluctuation of $\mathrm{pH}$ are depends on pond managements more than environmental conditions (Fig. 1). Variations in $\mathrm{pH}$ values coincided mainly with differences in photosynthetic activities. The lowest $\mathrm{pH}$ values appeared in ShaderAzam fish farms under two pond management systems (Fig. 1). The desirable pH range for most fish species is 6-9 (Shaker et. al., 2002 \& 2003 and Chanda and Musuka, 2012).

The $\mathrm{pH}$ values were significantly increased $(\mathrm{P}<0.05)$ in fertilizer fish ponds than feed fish ponds in three fish farms. These results may be due to increased phytoplankton in fertilizer ponds led to increased photosynthetic. This variation could be explained by the photosynthetic uptake of $\mathrm{CO}_{2}$ and bicarbonate that substituted hydroxyl ions. Pond water $\mathrm{pH}$ and $\mathrm{CO}_{2}$ concentration are affected by respiration and photosynthesis. Carbon dioxide is may build up in water as a result of respiration by aquatic animals and bacteria. In poorly buffered waters, this can cause a drop in $\mathrm{pH}$ below 7.0 that can inhibit nitrification. Aeration can drive of $\mathrm{CO}_{2}$, and in that process the $\mathrm{pH}$ is increased. Adequate alkalinity will ensure stable $\mathrm{pH}$ and provide carbon for nitrifying bacteria (Stephen, 2010).

Dissolved oxygen concentration in the water depends on water temperature and the proliferation of air with there is an inverse relationship between water temperature and solubility of oxygen in the water as well as on the process of photosynthesis by phytoplankton (Shaker et al., 2013; Boyd and McNevin, 2015). These results are in agreement with those obtained by Ayub and Boyd (1994); Boyd and Tucker (1998) who reported that the dissolved of oxygen from air to water decreased with increasing water temperature and Shaker et al. (2009a,b) who found the negative correlation between water temperature and dissolved oxygen values in water.

The SD readings were significantly $(\mathrm{P}<0.05)$ increased in TF fish ponds than others fish ponds. Also were significantly increasing in feed fish ponds than fertilizers fish ponds. These results clear that fertilization leads to increased growth of phytoplankton causing low reading transparency. These results are in agreement with those obtained by Shaker et al. (2003) and Shaker (2008).

From the presented data in Fig. (2), show the average values of nitrogen compounds $\left(\mathrm{NH}_{3}, \mathrm{NO}_{2}\right.$ and $\left.\mathrm{NO}_{3}\right)$ in ponds in each fish farm. Fertilization with inorganic and organic manure was considered as the source of nitrogen in all systems.Figure A note of nitrogenous compounds depends on fertilization first and 
then the remains of industrial feed and fish faeces and analyzed phytoplankton in addition to the decomposition of organic material in the soil.

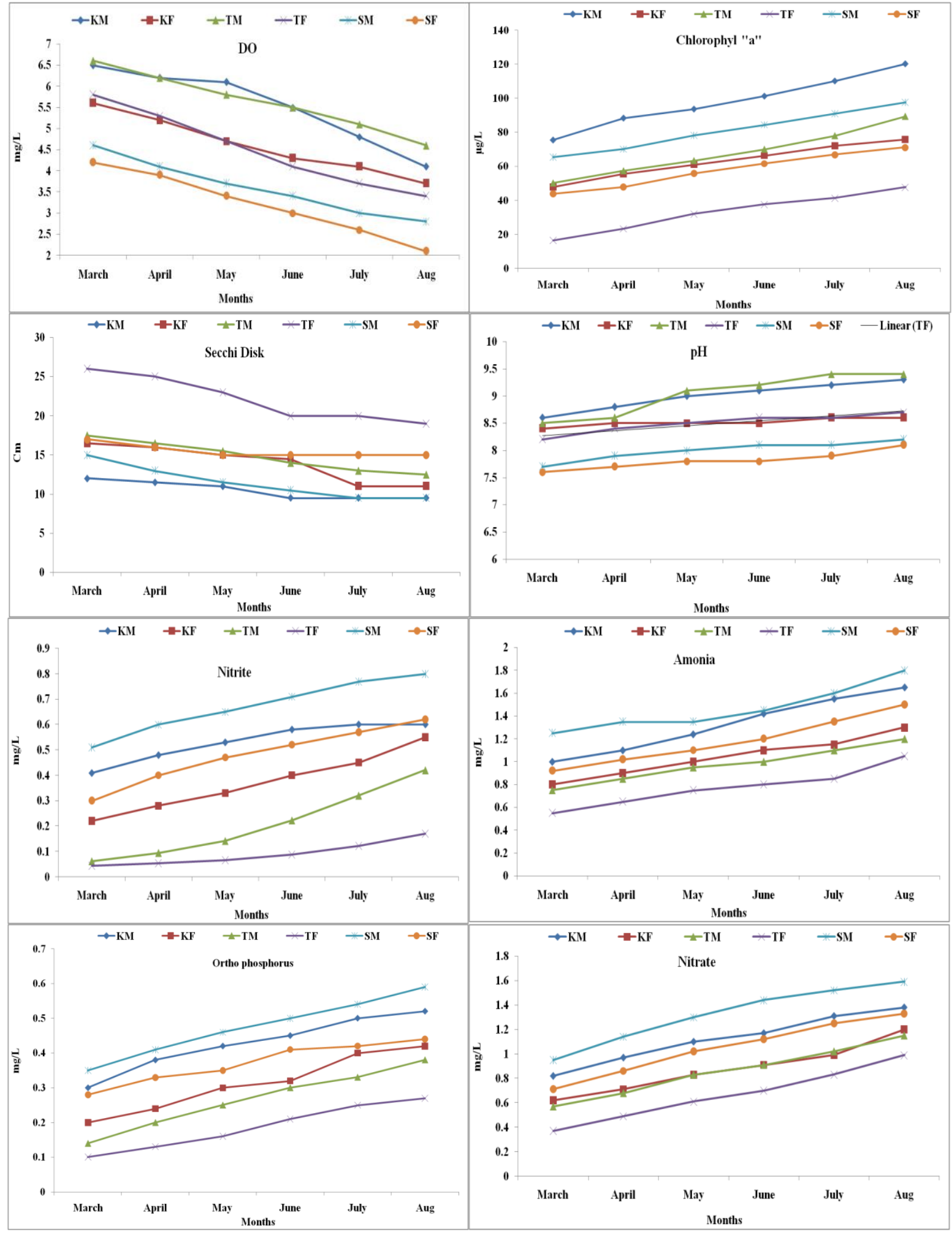

Fig. 2: Monthly fluctuations of $\mathrm{DO}, \mathrm{pH}, \mathrm{SD}, \mathrm{NH}_{3}, \mathrm{NO}_{2}, \mathrm{NO}_{3}$, orthophosphate and chlorophyll "a" in different fish farms as affected by different water sources and pond management. 
The nitrogen cycle in ponds is mostly microbial, the deamination of proteins producing ammonia. Further bacterial oxidation and reduction of nitrogen compounds iscoupled with photosynthetic assimilation and use by algae and aquatic macrophytes. The available nitrogen is then agminated into organic purines, pyrimidines, amino acids, etc., within the organism (Wetzel, 1975).

The highest values of nitrogen compound recorded in Shader Azam fish farm and the lowest values recorded in El-Tal El-Kabeer fish farm. The $\mathrm{NH}_{3} ; \mathrm{NO}_{2}$ and $\mathrm{NO}_{3}$ were significantly $(\mathrm{P}<0.05)$ increased in fertilizer fish ponds than feed fish ponds during all months in each fish farms. These results may be due to increased fish waste, residuals of artificial feed and organic fertilizer led to increase of organic compounds led to increase the decomposition process. These results are in agreement with those obtained by (Shaker, 2008). The $\mathrm{pH}$, nitrogen compounds and dissolved oxygen were the most influencing parameters in fish ponds, where their values in all ponds although fluctuated from time, to time they stayed within the acceptable and favorable levels required for growth, survival and wellbeing of the tested fish species.

Phosphorus is a key element involved in virtually all aspects of cellular metabolism, including phosphorylation reactions and synthesis of nucleo-tides, phosphorylated intermediate compounds, and various vitamins and enzymes. It is usually the limiting factor in plankton production in fresh- water systems (Boyd and McNevin, 2015). The most significant form of inorganic phosphorus is orthophosphate $\left(\mathrm{PO}_{4}\right)$; it can be rapidly removed from the water column and cycled throughout the system by various interactions of bacteria, protozoa, phytoplankton, zooplankton, and aquatic macrophytes (Dasgupta et al., 2008). Phosphorus can be absorbed both by acid bottom sediments and sediments that contain calcium carbonate (Dasgupta et al., 2008). These results clear that the average values of orthophosphate and chlorophyll "a" had positive correlation ship with fertilizer.

The highest values of orthophosphate and chlorophyll "a" recorded in Shader Azam fish farm and were significantly $(\mathrm{P}<0.05)$ increase in Shader Azam fish farm than others fish farm. Also, were significantly $(\mathrm{P}<0.05)$ increase in fertilizer fish farm than feed fish farms. These finding may be due to increase of organic fertilizer with increasing decomposition of organic matter led to release of nitrogen and $\mathrm{PO}_{4}$. Sevilleja et al. (2001) reported that there are several ways that phosphorus enters the water body and one of them is by organic manure decomposition. Organic manure in ponds decomposes and releases phosphorus which stimulates the growth of planktons and increase nutrient availability, leading to increased water quality and fish growth. The balance between nitrogen and phosphorus depends not only on their ratio in the water pond, but also on the processes controlling biogenic rotation and on their distribution in the aquatic ecosystem (Knoscheet al., 2000).

Phosphorus and chlorophyll "a" are the most important factors that help to increase the growth of natural food in the ponds. Fertilization is one of the main sources of increased nutrients that cause increased growth of phytoplankton. The same find by Ekpenyong (2000), who reported that Chlorophyll "a" is correlated to phytoplankton as increases in nutrient abundance in ponds give rise to increase in zooplankton production which in turn, reduces the phytoplankton biomass through grazing and as such chlorophyll "a" is reduced.

According to ranges specified by Shaker (2008); Boyd and McNevin 2015 and Shaker et al. (2015) all values determined in this study were adequate levels for fish culture.

Both fertilizers and artificial feed communities were composed of four groups of algae: Bacillariophyceae, Chlorophyceae, Cyanophyceae and Euglenophyceae, and 
four groups of zooplankton: Cladocera; Copepoda; Ostracoda and Rotifra.. For the phytoplankton, the Chlorophyceae was the dominant group of phytoplankton in terms of number of cells or colony-forming units, followed by Bacillariophyceae, Euglenophyceae and Cyanophyceae in all treatments (Fig. 2). There was significant $(\mathrm{P}<0.05)$ difference in abundance in all groups of phytoplankton or zooplankton among pond managements and fish farms. Abundance increased significantly over the experimental period and fertilizers ponds.

Average and total numbers of phytoplankton and zooplankton are presented in Figs. (3\&4). Phytoplankton growth depends on the availability of nutrients in the water, especially nitrogen and phosphorus. The fertilizer fish ponds in Kafer El-Sheik had significantly increase $(\mathrm{P}<0.05)$ than others fish farms. Chlorophyta numbers had direction Kafr El-Sheikh followed by Shader Azzam then El-Tal El-Kabeer. The same trend was observed by Bacillarophyta. The Cyanophyta and Euglina numbers had significantly increase $(\mathrm{P}<0.05)$ in in Kafer El-Sheik and Shader Azzam fish farms.

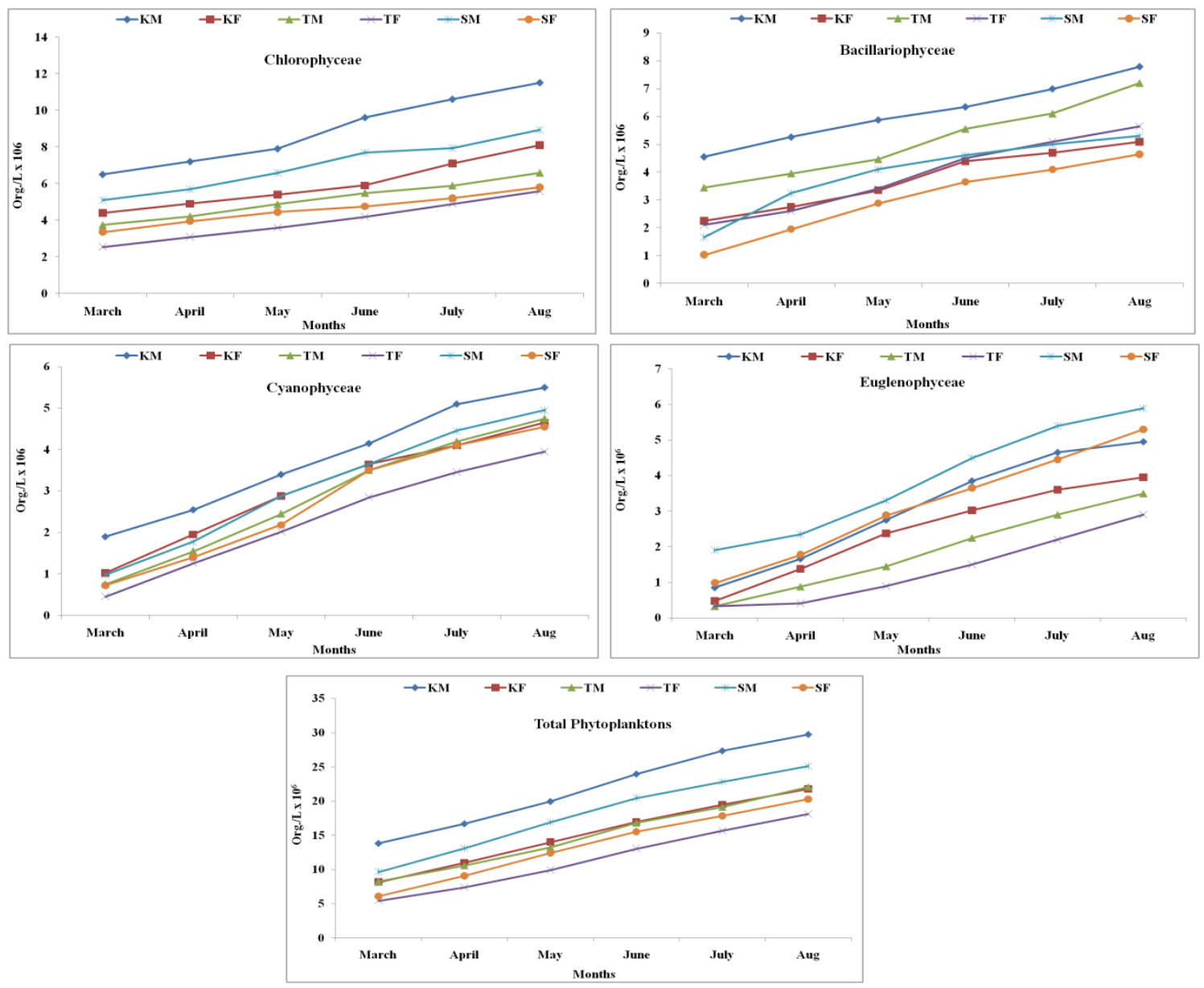

Fig. 3: Monthly fluctuations of phytoplankton in different fish farms as affected by different water sources and pond management.

Increase of Cyanophyta and Euglina numbers in the waters in Kafer El-Sheik and Shader Azzam fish farms it means that the water is highly contaminated. Also, lower numbers of Cyanophyta and Euglina numbers in the waters of the El Tal El Kabeer refers to the good water quality and purity. These results are in agreement with those obtained by Shaker (2008) and Shaker et al., (2016), who reported that the 
Cyanophyta and Euglina numbers had significantly increase $(\mathrm{P}<0.05)$ with increasing organic and inorganic pollutants in water.

Many studies have shown that the combined use of inorganic and organic fertilizers is effective in productivity improvement in earthen ponds (Afzal et al., 2007; Jha et al., 2008). Moreover, the combined use of inorganic and organic fertilizers is effective in maintaining phytoplankton and zooplankton population in production ponds. Fertilizers are applied for fertilization of fish ponds to increase plant nutrients contraction and to stimulate natural fish growth and ultimately increase fish production. Availability of natural food in pond water reduces fish demand for artificial feeds, leading to reduce production costs and improve farm income. Manure has been used extensively as organic fertilizers in fish farms for increasing natural food web and consequently reducing production costs.

Fish harvest and economic performance:

The applications of organic and inorganic fertilizer in ponds water enhance plankton productivity and abundance which support fish production (Jhaet al., 2008). Manipulation of organic manure and feed inputs can increase production in earthen ponds especially for herbivore fish such as tilapia, common carp and mullet (Edwards et al., 1994). The use of organic and mineral fertilizers leads to increased plankton growth and reduce the cost of production of fish, Shaker et al. (2016). The growth performance and harvest volume of Nile tilapia and mullet in the three fish farms under two farming systems are shown in Table (1) and Fig. (4).

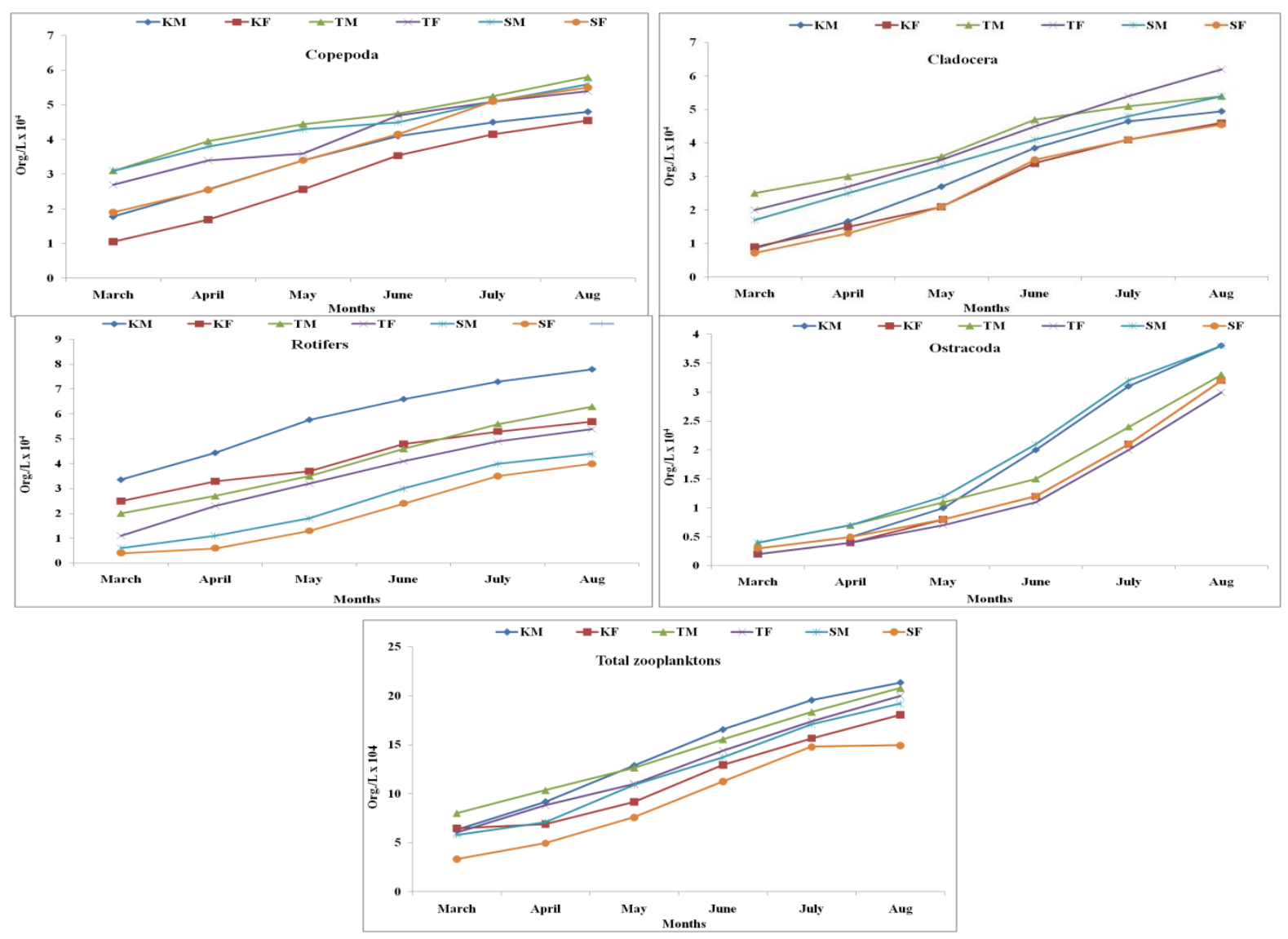

Fig. 4: Monthly fluctuations of zooplankton in different fish farms as affected by different water sources and pond management. 
Table 1: Growth performance of tilapia and mullet in different fish farms as affected by different water sources and pond management.

\begin{tabular}{|c|c|c|c|c|c|c|c|c|c|c|c|c|}
\hline \multirow{3}{*}{$\begin{array}{l}\text { Locations } \\
\text { Mantgement } \\
\text { Items }\end{array}$} & \multicolumn{4}{|c|}{ Kafer El-Sheik } & \multicolumn{4}{|c|}{ El Tal El Kabeer } & \multicolumn{4}{|c|}{ ShaderAzam } \\
\hline & \multicolumn{2}{|c|}{ Fertilizer } & \multicolumn{2}{|c|}{ feed } & \multicolumn{2}{|c|}{ fertilizer } & \multicolumn{2}{|c|}{ Feed } & \multicolumn{2}{|c|}{ fertilizer } & \multicolumn{2}{|c|}{ feed } \\
\hline & tilapia & Mullet & Tilapia & mullet & tilapia & mullet & tilapia & Mullet & Tilapia & mullet & tilapia & mullet \\
\hline $\begin{array}{l}\text { Initial Weight } \\
\text { (g) }\end{array}$ & $\begin{array}{c}2 \\
\pm \\
0.0 \mathrm{a}\end{array}$ & $\begin{array}{c}30 \\
\pm \\
1.5 \mathrm{a}\end{array}$ & $\begin{array}{c}2 \\
\pm \\
0.0 \mathrm{a}\end{array}$ & $\begin{array}{c}30 \\
\pm \\
2.0 \mathrm{a}\end{array}$ & $\begin{array}{c}2 \\
\pm \\
0.0 \mathrm{a}\end{array}$ & $\begin{array}{c}30 \\
\pm \\
1.5 \mathrm{a}\end{array}$ & $\begin{array}{c}2 \\
\pm \\
0.0 \mathrm{a}\end{array}$ & $\begin{array}{c}30 \\
\pm \\
2.0 \mathrm{a}\end{array}$ & $\begin{array}{c}2 \\
\pm \\
0.0 \mathrm{a}\end{array}$ & $\begin{array}{c}30 \\
\pm \\
1.5 \mathrm{a}\end{array}$ & $\begin{array}{c}2 \\
\pm \\
0.0 \mathrm{a}\end{array}$ & $\begin{array}{c}30 \\
\pm \\
2.0 \mathrm{a}\end{array}$ \\
\hline Initial Number & $\begin{array}{c}16000 \\
\pm \\
100 \mathrm{a}\end{array}$ & $\begin{array}{c}4000 \\
\pm \\
30 \mathrm{a}\end{array}$ & $\begin{array}{c}16000 \\
\pm \\
100 \mathrm{~b}\end{array}$ & $\begin{array}{l}4000 \\
\pm \\
25 \mathrm{a}\end{array}$ & $\begin{array}{c}16000 \\
\pm \\
100 \mathrm{a}\end{array}$ & $\begin{array}{c}4000 \\
\pm \\
25 \mathrm{a}\end{array}$ & $\begin{array}{c}16000 \\
\pm \\
100 \mathrm{~b}\end{array}$ & $\begin{array}{c}4000 \\
\pm \\
25 \mathrm{a}\end{array}$ & $\begin{array}{c}16000 \\
\pm \\
100 \mathrm{a}\end{array}$ & $\begin{array}{c}4000 \\
\pm \\
30 \mathrm{a}\end{array}$ & $\begin{array}{c}16000 \\
\pm \\
100 \mathrm{~b}\end{array}$ & $\begin{array}{c}4000 \\
\pm \\
30 \mathrm{a}\end{array}$ \\
\hline $\begin{array}{l}\text { Total Initial } \\
\text { Weight (g) }\end{array}$ & $\begin{array}{c}32000 \\
\pm \\
200 \mathrm{a} \\
\end{array}$ & $\begin{array}{c}12000 \\
\pm \\
500 \mathrm{a} \\
\end{array}$ & $\begin{array}{c}32000 \\
\pm \\
200 \mathrm{~b} \\
\end{array}$ & $\begin{array}{c}12000 \\
\pm \\
500 \mathrm{a} \\
\end{array}$ & $\begin{array}{c}32000 \\
\pm \\
200 \mathrm{a} \\
\end{array}$ & $\begin{array}{c}12000 \\
\pm \\
500 \mathrm{a} \\
\end{array}$ & $\begin{array}{c}32000 \\
\pm \\
200 \mathrm{~b} \\
\end{array}$ & $\begin{array}{c}12000 \\
\pm \\
500 \mathrm{a} \\
\end{array}$ & $\begin{array}{c}32000 \\
\pm \\
200 \mathrm{a} \\
\end{array}$ & $\begin{array}{c}12000 \\
\pm \\
500 \mathrm{a} \\
\end{array}$ & $\begin{array}{c}32000 \\
\pm \\
200 \mathrm{~b}\end{array}$ & $\begin{array}{c}12000 \\
\pm \\
500 \mathrm{a}\end{array}$ \\
\hline $\begin{array}{l}\text { Average final } \\
\text { Weight }(\mathrm{g})\end{array}$ & $\begin{array}{c}185 \\
\pm \\
15 \mathrm{~d}\end{array}$ & $\begin{array}{c}200 \\
\pm \\
12 \mathrm{c}\end{array}$ & $\begin{array}{c}250 \\
\pm \\
25 \mathrm{~b}\end{array}$ & $\begin{array}{c}210 \\
\pm \\
15 \mathrm{c}\end{array}$ & $\begin{array}{c}175 \\
\pm \\
25 \mathrm{e}\end{array}$ & $\begin{array}{c}185 \\
\pm \\
25 \mathrm{~d}\end{array}$ & $\begin{array}{c}250 \\
\pm \\
25 \mathrm{~b}\end{array}$ & $\begin{array}{c}205 \\
\pm \\
25 \mathrm{c}\end{array}$ & $\begin{array}{c}200 \\
\pm \\
25 \mathrm{c}\end{array}$ & $\begin{array}{c}230 \\
\pm \\
25 \mathrm{~b}\end{array}$ & $\begin{array}{c}285 \\
\pm \\
25 \mathrm{a}\end{array}$ & $\begin{array}{c}250 \\
\pm \\
25 \mathrm{a}\end{array}$ \\
\hline Survival Rate \% & $\begin{array}{c}93.2 \\
\pm \\
3.5 \mathrm{~b}\end{array}$ & $\begin{array}{c}87.5 \\
\pm \\
2.5 \mathrm{~b}\end{array}$ & $\begin{array}{c}98.22 \\
\pm \\
1.2 \mathrm{a}\end{array}$ & $\begin{array}{c}86.5 \\
\pm \\
2 \mathrm{~b}\end{array}$ & $\begin{array}{c}94.5 \\
\pm \\
1.5 \mathrm{~b}\end{array}$ & $\begin{array}{c}90.0 \\
\pm \\
2 \mathrm{a}\end{array}$ & $\begin{array}{c}95.5 \\
\pm \\
1.5 \mathrm{~b}\end{array}$ & $\begin{array}{c}90.0 \\
\pm \\
2 \mathrm{a}\end{array}$ & $\begin{array}{c}95.0 \\
\pm \\
1 \mathrm{~b}\end{array}$ & $\begin{array}{c}90.0 \\
\pm \\
3 \mathrm{a}\end{array}$ & $\begin{array}{c}95.0 \\
\pm \\
2 \mathrm{~b}\end{array}$ & $\begin{array}{c}91.5 \\
\pm \\
1.5 \mathrm{a}\end{array}$ \\
\hline Final Number & $\begin{array}{c}14912 \\
\pm \\
120 \mathrm{~d}\end{array}$ & $\begin{array}{c}3500 \\
\pm \\
45 \mathrm{~b}\end{array}$ & $\begin{array}{c}15715 \\
\pm \\
120 \mathrm{a}\end{array}$ & $\begin{array}{c}3460 \\
\pm \\
50 \mathrm{~b}\end{array}$ & $\begin{array}{c}15120 \\
\pm \\
110 \mathrm{~b}\end{array}$ & $\begin{array}{c}3600 \\
\pm \\
52 \mathrm{a}\end{array}$ & $\begin{array}{c}15280 \\
\pm \\
123 \mathrm{~b}\end{array}$ & $\begin{array}{c}3600 \\
\pm \\
22 \mathrm{a}\end{array}$ & $\begin{array}{c}15280 \\
\pm \\
114 \mathrm{~b}\end{array}$ & $\begin{array}{c}3600 \\
\pm \\
28 \mathrm{a}\end{array}$ & $\begin{array}{c}15280 \\
\pm \\
144 \mathrm{~b}\end{array}$ & $\begin{array}{c}3660 \\
\pm \\
32 \mathrm{a}\end{array}$ \\
\hline $\begin{array}{c}\text { Total Final } \\
\text { Weight }(\mathrm{kg})\end{array}$ & $\begin{array}{c}2758.7 \\
\pm \\
55 \mathrm{~d}\end{array}$ & $\begin{array}{c}700 \\
\pm \\
15 \mathrm{~d}\end{array}$ & $\begin{array}{c}3928.8 \\
\pm \\
72 \mathrm{~b}\end{array}$ & $\begin{array}{c}764.4 \\
\pm \\
14 \mathrm{c}\end{array}$ & $\begin{array}{c}2646 \\
\pm \\
26 \mathrm{e}\end{array}$ & $\begin{array}{c}666 \\
\pm \\
12 \mathrm{~d}\end{array}$ & $\begin{array}{c}3820 \\
\pm \\
22 \mathrm{~b}\end{array}$ & $\begin{array}{c}738 \\
\pm \\
8 \mathrm{c}\end{array}$ & $\begin{array}{c}3056 \\
\pm \\
16 \mathrm{c}\end{array}$ & $\begin{array}{c}828 \\
\pm \\
14 \mathrm{~b}\end{array}$ & $\begin{array}{c}4355 \\
\pm \\
54 \mathrm{a}\end{array}$ & $\begin{array}{c}900 \\
\pm \\
12 \mathrm{a}\end{array}$ \\
\hline Net Gain/fish (g) & $\begin{array}{c}183 \\
\pm \\
11 \mathrm{~d} \\
\end{array}$ & $\begin{array}{c}170 \\
\pm \\
10 \mathrm{~d}\end{array}$ & $\begin{array}{c}248 \\
\pm \\
14 \mathrm{~b}\end{array}$ & $\begin{array}{c}180 \\
\pm \\
11 \mathrm{c}\end{array}$ & $\begin{array}{c}173 \\
\pm \\
11 \mathrm{e}\end{array}$ & $\begin{array}{c}155 \\
\pm \\
11 \mathrm{e}\end{array}$ & $\begin{array}{c}248 \\
\pm \\
14 \mathrm{~b}\end{array}$ & $\begin{array}{c}175 \\
\pm \\
12 \mathrm{~d} \\
\end{array}$ & $\begin{array}{c}198 \\
\pm \\
11 \mathrm{c}\end{array}$ & $\begin{array}{c}200 \\
\pm \\
12 \mathrm{~b}\end{array}$ & $\begin{array}{c}283 \\
\pm \\
8 \mathrm{a}\end{array}$ & $\begin{array}{c}220 \\
\pm \\
14 \mathrm{a} \\
\end{array}$ \\
\hline Daily Gain (g) & $\begin{array}{c}1.22 \\
\pm \\
0.01 \mathrm{~d}\end{array}$ & $\begin{array}{c}1.13 \\
\pm \\
0.01 \mathrm{c}\end{array}$ & $\begin{array}{c}1.65 \\
\pm \\
0.05 \mathrm{~b}\end{array}$ & $\begin{array}{c}1.2 \\
\pm \\
0.01 \mathrm{c}\end{array}$ & $\begin{array}{c}1.15 \\
\pm \\
0.02 \mathrm{~d}\end{array}$ & $\begin{array}{c}1.03 \\
\pm \\
0.02 \mathrm{~d}\end{array}$ & $\begin{array}{c}1.65 \\
\pm \\
0.03 \mathrm{~b}\end{array}$ & $\begin{array}{c}1.13 \\
\pm \\
0.02 \mathrm{c}\end{array}$ & $\begin{array}{c}1.32 \\
\pm \\
0.01 \mathrm{c}\end{array}$ & $\begin{array}{c}1.33 \\
\pm \\
0.02 \mathrm{~b}\end{array}$ & $\begin{array}{c}1.89 \\
\pm \\
0.02 \mathrm{a}\end{array}$ & $\begin{array}{c}1.47 \\
\pm \\
0.01 \mathrm{a}\end{array}$ \\
\hline Total Gain (kg) & $\begin{array}{c}2728.9 \\
\pm \\
122 \mathrm{e}\end{array}$ & $\begin{array}{c}630 \\
\pm \\
22 \mathrm{c}\end{array}$ & $\begin{array}{c}3897.3 \\
\pm \\
112 \mathrm{~b}\end{array}$ & $\begin{array}{c}622.8 \\
\pm \\
19 \mathrm{c}\end{array}$ & $\begin{array}{c}2615.8 \\
\pm \\
12 \mathrm{e}\end{array}$ & $\begin{array}{c}558 \\
\pm \\
14 \mathrm{~d}\end{array}$ & $\begin{array}{c}3789.4 \\
\pm \\
127 \mathrm{c}\end{array}$ & $\begin{array}{c}630 \\
\pm \\
17 \mathrm{c}\end{array}$ & $\begin{array}{c}3025.4 \\
\pm \\
119 \mathrm{~d}\end{array}$ & $\begin{array}{c}720 \\
\pm \\
13 \mathrm{~b}\end{array}$ & $\begin{array}{c}4324.2 \\
\pm \\
119 \mathrm{a}\end{array}$ & $\begin{array}{c}805.2 \\
\pm \\
17 \mathrm{a}\end{array}$ \\
\hline S.G.R. & $\begin{array}{c}2.84 \\
\pm \\
0.13 \mathrm{e}\end{array}$ & $\begin{array}{c}1.16 \\
\pm \\
0.02 \mathrm{~b}\end{array}$ & $\begin{array}{c}3.22 \\
\pm \\
0.11 \mathrm{~b}\end{array}$ & $\begin{array}{c}1.19 \\
\pm \\
0.03 \mathrm{~b}\end{array}$ & $\begin{array}{c}2.98 \\
\pm \\
0.02 \mathrm{~d}\end{array}$ & $\begin{array}{c}1.096 \\
\pm \\
0.01 \mathrm{c}\end{array}$ & $\begin{array}{c}3.22 \\
\pm \\
0.03 \mathrm{~b}\end{array}$ & $\begin{array}{c}1.18 \\
\pm \\
0.01 \mathrm{~b}\end{array}$ & $\begin{array}{c}3.07 \\
\pm \\
0.02 \mathrm{c}\end{array}$ & $\begin{array}{c}1.27 \\
\pm \\
0.02 \mathrm{a}\end{array}$ & $\begin{array}{c}3.31 \\
\pm \\
0.04 \mathrm{a}\end{array}$ & $\begin{array}{c}1.33 \\
\pm \\
0.02 \mathrm{a}\end{array}$ \\
\hline T. Prod./Kg /Fed. & 3458 & $02 \mathrm{e}$ & 4693 & $36 b$ & 331 & $92 \mathrm{e}$ & 455 & $26 c$ & 388 & $10 \mathrm{~d}$ & 52 & $72 \mathrm{a}$ \\
\hline
\end{tabular}

Tilapia and mullet was stocked at the same initial numbers and initial weight in three fish farms ponds under two farming systems. The survival rates of tilapia were 95.71; 95.0; 95 and mullet were 87.0; 90 and 90.75\% in Kafer El-Sheik; El Tal El Kabeer and Shader Azam respectively regardless pond managements. These results indicated that the survival rates were not significantly $(\mathrm{P}<0.05)$ differing among three fish farms. The survival rate of tilapia were 93.2- 94.5 - 95\% in fertilizers fish ponds and in feed fish ponds were 98.22- 95.5 -95\% in Kafer El-Sheik; El Tal El Kabeer and Shader Azam respectively. The survival rates (\%) in feed ponds systems were significantly $(\mathrm{P}<0.05)$ higher than in fertilizers fish ponds. These results it probably due to increased growths phytoplankton in the early stages of cultivation led to increased consumption of dissolved oxygen in water. Also, the survival rate of tilapia were significantly $(\mathrm{P}<0.05)$ increased than in mullet in each fish farms. The daily weight average (1.22 - 1.15 and 132) for tilapia fertilizers fish ponds, $(1.65,1.65$ and 1.89) for tilapia feed fish ponds in Kafer El-Sheik; El Tal El Kabeer and Shader Azam respectively. The daily weight average $(1.13,1.03$ and 1.33) for mullet fertilizers fish ponds $(1.2,1.13$ and 1.47) for feed fish pond in Kafer El-Sheik; El Tal El Kabeer and Shader Azam respectively. These results indicated that the daily weight gain of tilapia was significantly higher $(\mathrm{P}<0.05)$ than mullet. The same trend was observed by SGR. These results are good in agreement with those obtained by Yang et al. (2003); Shaker and Abd El Aal, (2006); Shaker (2008) and Shaker et al. (2016) who reported that the daily gain and SGR of catfish was significantly $(\mathrm{P}<0.05)$ higher than daily gain 
tilapia, silver carp, common carp and mullet. They added that the daily gain and SGR of tilapia was significantly $(\mathrm{P}<0.05)$ than mullet. Overall, the daily gain and SGR of tilapia and mullet were significantly $(\mathrm{P}<0.05)$ higher in feed pond systems than in fertilizers ponds system in all fish farms. These results are good agreement with those obtained by Shaker et al. (2016).

The total production of fish were $3458.7,4693.2,3312,4558,3884$ and $5255 \mathrm{~kg} /$ feddan for KM; KF; TF; TM; PM and PF fish farm respectively (Fig. 5). These results clear that the total fish production per feddan Shader Azam was significantly $(\mathrm{P}<0.05)$ higher followed by Kafer El-Sheik and then El Tal El Kabeer respectively.

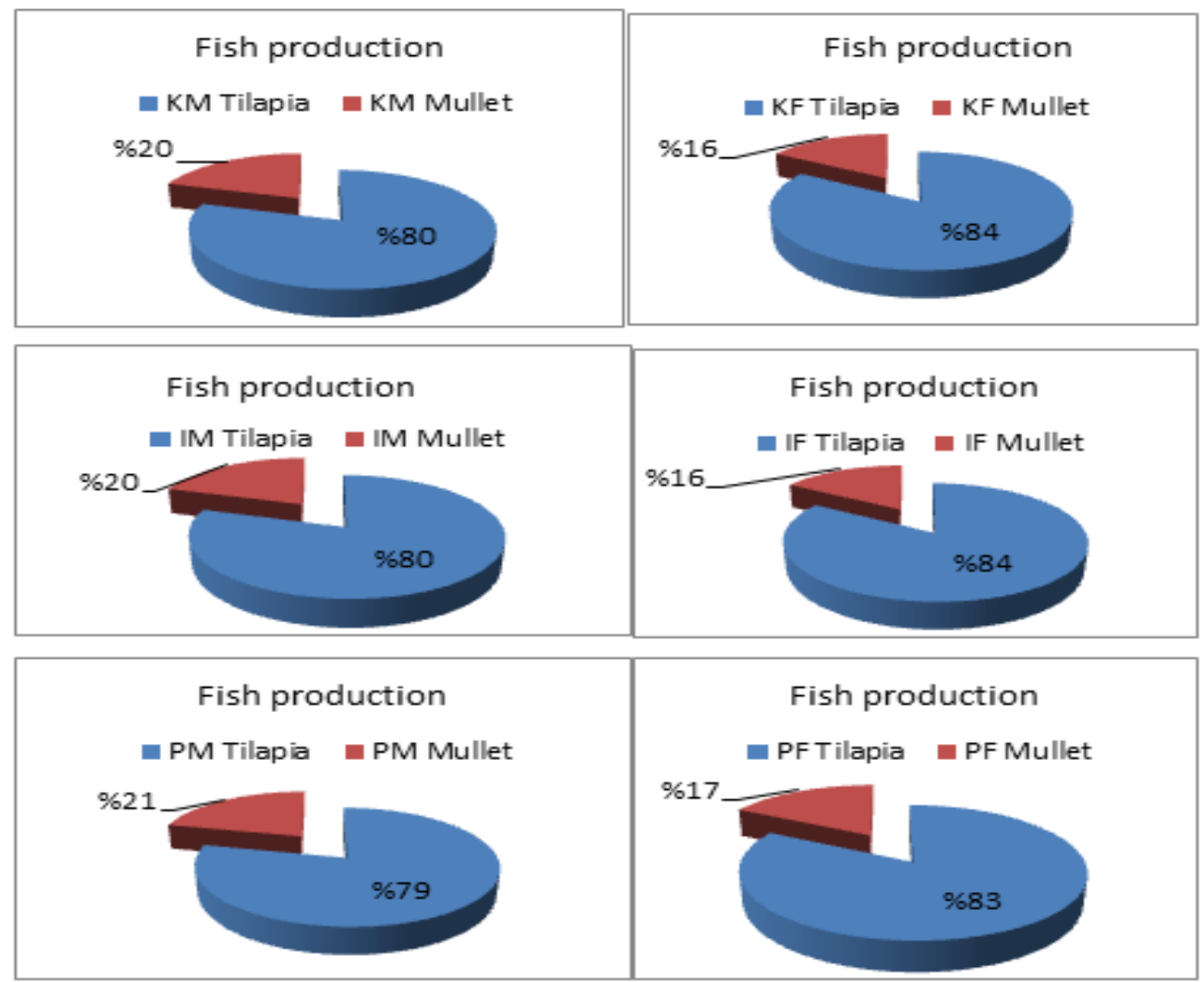

Fig. 5: Production of tilapia and mullet as percentage in different fish farmsunder different pond managements in each governorate.

Also, the feed fish farm ponds were significantly $(\mathrm{P}<0.05)$ higher $(\mathrm{P}<0.05)$ than fertilizer fish farm ponds in each fish farms. These results indicated the fertilizer system was not suitable for Nile tilapia growth during the whole period, while artificial feed systems offered more nutritional support during different development. The increasing fish production in Shader Azzam fish farms (fertilizers and feed) as a result of increased organic waste, zooplankton and benthos. The production rates of mullet were significantly $(\mathrm{P}<0.05)$ increased in fertilizers system than in feed system. These results indicate that the mullet needs to fertilization with artificial feed. These results are good in agreement with those obtained by Shaker (2008) and Shaker et al. (2016), who reported that the highest fish production recorded in traditional (organic and mineral fertilizers + artificial feed) fish ponds. He added that the cost of fish production in the fertilizer system was significantly less than artificial feed system. From the presented data in Table (2) and Fig. (6) show, the production and distribution of output on various grades and yield economic. The production of tilapia 
distributed to five degrees (Dabbashi, Super, Grad1, Grad2, and Gard3) in fertilizers fish ponds, while the production of tilapia distributed to four degrees (Dabbashi, Super, Grad1 and Grad2) in feed fish ponds and the production of mullet spread to two degrees (Grad1 and2). The economics efficiency of ponds management is shown in Table (2). The cost of fingerlings per feddan were 5280 LE in feed and fertilizer and feed fish farm which amount to 23.18,12.9, 22.34, 13.53, 23.23 and 14.69\% of total operating costs in KM; KF; IF; IM; PM and PF fish farm respectively. The cost of feed per feddan were 10250, 32500,10550,30750,10450 and 27500LE which amount to $44.99,79.4,44.65,78.78,45.97$ and $76.53 \%$ of total operating costs in KM; KF; IF; IM; PM and PF fish farm respectively. The total production cost per feddan were 22780,40930,23630,39030, 22730 and 35930LE in KM; KF; IF; IM; PM and PF fish farm respectively. The total returns of Tilapia and mullet were 22780, 40930, 23630, 39030, 22730 and 35930L.E in the same fish farms respectively.

Table 2: Economic efficiency of pond management in feed and fertilizer fish farms in Kafer El-Sheik El; Tal El Kabeer and ShaderAzam.

\begin{tabular}{|c|c|c|c|c|c|c|}
\hline \multirow{2}{*}{ Items } & \multicolumn{2}{|c|}{ Kafer El-Sheik } & \multicolumn{2}{|c|}{ El Tal El Kabeer } & \multicolumn{2}{|c|}{ ShaderAzam } \\
\hline & $\begin{array}{c}\text { Fertilizer fish } \\
\text { farm }\end{array}$ & $\begin{array}{l}\text { Feed fish } \\
\text { farm }\end{array}$ & $\begin{array}{l}\text { Fertilizer } \\
\text { fish farm }\end{array}$ & $\begin{array}{l}\text { Feed fish } \\
\text { farm }\end{array}$ & $\begin{array}{l}\text { Fertilizer } \\
\text { fish farm }\end{array}$ & $\begin{array}{l}\text { Feed fish } \\
\text { farm }\end{array}$ \\
\hline $\begin{array}{l}\text { Fingerlings cost } \\
\text { Tilapia }\end{array}$ & 1280 & 1280 & 1280 & 1280 & 1280 & 1280 \\
\hline Mullet & 4000 & 4000 & 4000 & 4000 & 4000 & 4000 \\
\hline Total cost of fish & 5280 & 5280 & 5280 & 5280 & 5280 & 5280 \\
\hline Feed cost & 10250 & 32500 & 10550 & 30750 & 10450 & 27500 \\
\hline Fertilizer coast & 4000 & - & 4800 & - & 3750 & - \\
\hline Labor coast & 500 & 500 & 500 & 500 & 500 & 500 \\
\hline Irrigation coast & 750 & 650 & 500 & 500 & 750 & 650 \\
\hline Total cost of management & 20780 & 38930 & 21630 & 37030 & 20730 & 33930 \\
\hline Depreciation & 2000 & 2000 & 2000 & 2000 & 2000 & 2000 \\
\hline Total cost LE & 22780 & 40930 & 23630 & 39030 & 22730 & 35930 \\
\hline \multicolumn{7}{|l|}{$\begin{array}{l}\text { Harvest fish size grand }(\mathrm{Kg}) \\
\text { Tilapia }\end{array}$} \\
\hline Dabbashi & 103 & 506 & 145 & 535 & 400 & 650 \\
\hline Super & 295 & 900 & 315 & 895 & 810 & 955 \\
\hline Grad 1 & 1375 & 1572.8 & 1225 & 1515 & 1110 & 1575 \\
\hline Grad 2 & 735.7 & 925 & 703 & 868 & 736 & 1165 \\
\hline Gard 3 & 250 & 25 & 258 & 17 & - & 10 \\
\hline \multicolumn{7}{|l|}{ Mullet } \\
\hline Grad 1 & 135 & 310 & 175 & 345 & 400 & 450 \\
\hline Grad 2 & 565 & 454 & 491 & 393 & 428 & 450 \\
\hline \multicolumn{7}{|l|}{ Sale price of fish (LE) } \\
\hline \multicolumn{7}{|l|}{ Tilapia } \\
\hline Dabbashi12 LE & 1236 & 6072 & 1740 & 6300 & 4800 & 7800 \\
\hline Supper $11 \mathrm{LE}$ & 3245 & 9900 & 3465 & 9845 & 8910 & 10505 \\
\hline $110 \mathrm{LE}$ & 13750 & 15728 & 12250 & 15150 & 11100 & 15750 \\
\hline $8 \mathrm{LE}$ & 5885.6 & 7400 & 5624 & 6944 & 5888 & 9320 \\
\hline $6 \mathrm{LE}$ & 1500 & 150 & 1548 & 102 & - & 60 \\
\hline Total sale price of tilapia & 25617.6 & 39250 & 24627 & 38341 & 30698 & 43435 \\
\hline \multicolumn{7}{|l|}{ Mullet } \\
\hline $27 \mathrm{LE}$ & 3645 & 8370 & 4725 & 9315 & 10800 & 12150 \\
\hline $22 \mathrm{LE}$ & 12340 & 9988 & 10802 & 8646 & 9416 & 9900 \\
\hline Total sale price of mullet & 16075 & 18358 & 15527 & 17961 & 20216 & 22050 \\
\hline Total revenues of fish & 41691.6 & 57608 & 40154 & 56320 & 50914 & 65485 \\
\hline Total cost & 22780 & 40930 & 23630 & 39030 & 22730 & 35930 \\
\hline Average cost/ Kg & 6.59 & 8.72 & 7.13 & 8.56 & 5.85 & 6.83 \\
\hline Average price $/ \mathrm{kg}$ & 12.05 & 12.27 & 12.12 & 12.35 & 13.11 & 12.46 \\
\hline Return above coast/ kg & 5.46 & 3.55 & 4.99 & 3.79 & 7.26 & 5.63 \\
\hline Rate of return to capital (\%) & 82.86 & 40.71 & 69.99 & 44.28 & 124.1 & 82.43 \\
\hline
\end{tabular}



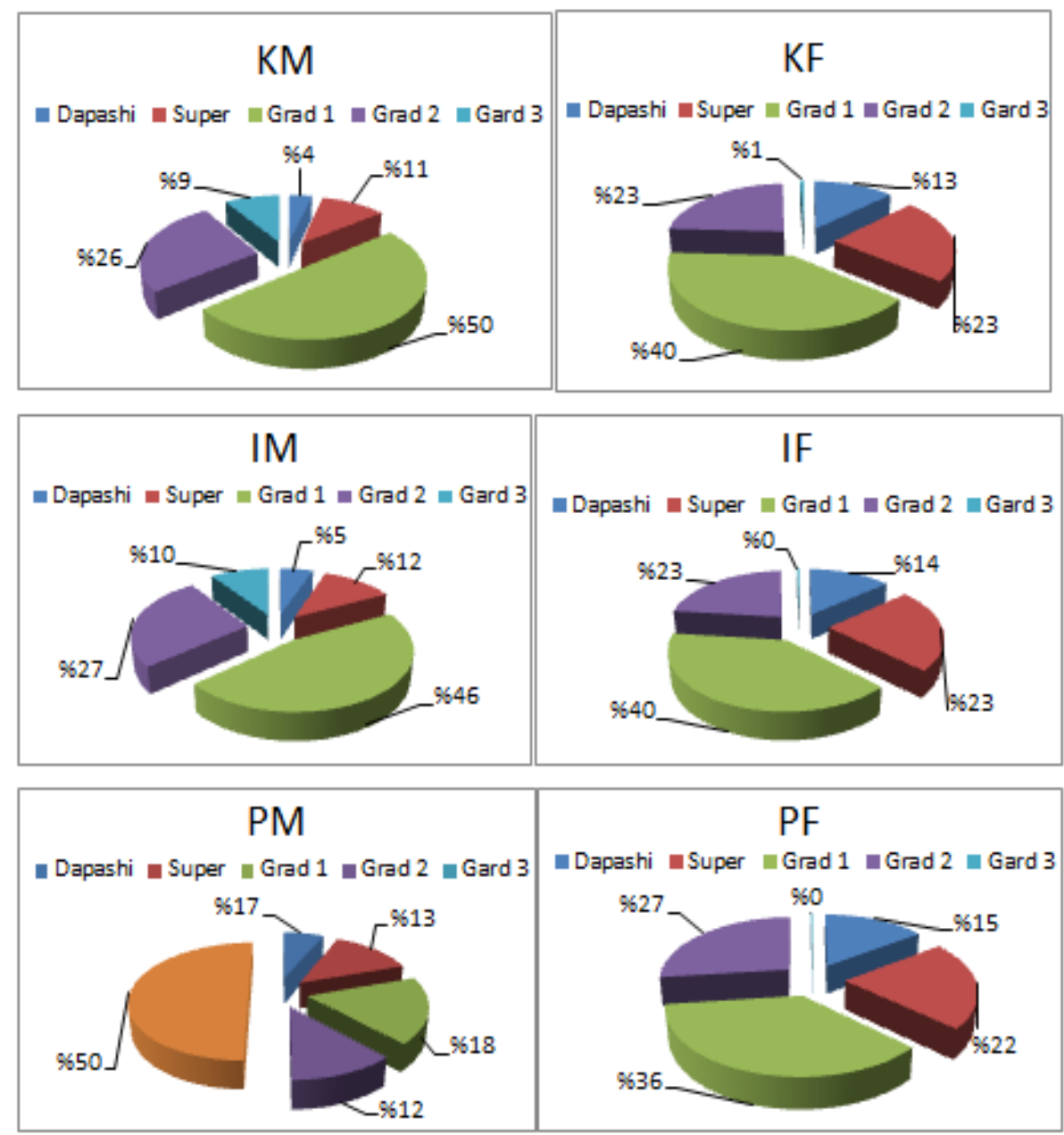

Fig. 6: Production of tilapia as percentage grads in different fish farmsunder different pond managements in each governorate.

The production costs per kilogram of fish were $6.59,8.72,7.13,8.56,5.85$ and 6.83LE in KM; KF; IF; IM; PM and PF fish farm respectively. The respective total sale income averaged 22780, 40930, 23630, 39030, 22730 and 35930 LE for the same treatments respectively, resulting in returns above total coast as 5.46, 3.55 4.99,3.79, 7.26 and 6.99 LE per kilogram of fish in KM; KF; IF; IM; PM and PF fish farm respectively. The highest total returns was observed in the feed fish farm due to increased fish production and higher quality of fish harvest in terms of size grades composition, especially the higher percentage of Dabbashi, super and first class of Tilapia and mullet. While, the total income per feddan was higher in the feed fishfarm, the net income was significantly higher $(\mathrm{P}<0.05)$ in the fertilizer fish farm due to its lower operating costs per unit of production.

In conclusion, increased total production of fish in artificial feeding fish farms ponds than fertilizers fish pond., Increase output proportion of Dabbashi super and first class in artificial feeding transactions compared with than fertilizers fish pond. And Absence of Tilapia in the third degree in artificial feeding fish farms ponds.

Clearly, the factors having the greatest impact on the economic outcome were the yield as consequence of growth and survival, prices received for tilapia and mullet at different size groups, feed, and fingerlings of tilapia and mullet costs. 


\section{REFRENCESS}

Abd El-Hakim, N.F.; Abo State, H.A.; Al-Azab, A.A. and El-Kholy, K. (2009). Effect of feeding regimes on growth performance of juvenile hybrid tilapia (Oreochromisniloticus $x$ Oreochromis aureus).World J. Agric. Sci., 5(1):49-54.

Afzal, M.; Rubm, A.; Akhtar, N.; Khan, M.F.; Barlas, A. and Qayyum, M. (2007). Effect of organic and inorganic fertilizers on the growth performance of bighead carp (Aristicthysnobilis) in polyculture system. Int. J. Agri. Biol., 9(6):931-933.

American Public Health Association (APHA) (2000). Standard Methods for the Examination of Water and waste water (20th edition).Washington, D.C. Amin.

Ayub, M. and Boyd, C.E. (1994). Comparison of different methods for measuring organic carbon in pond bottom soils. J. Aquacult. Soc., 25:322-325.

Boyd, C.E. and Tucker, C.S. (1998). Water Quality and Pond Soil Analysis for Aquaculture., Alabama agriculture Experiment Station, Alabama, USA.700pp.

Boyd, C.E. and McNevin, A.A. (2015). Aquaculture resource use and environmental.Published by John Wily and Sons, Inc.

Chanda, K. and Musuka, C. (2012). Determination of chlorophyll a and total phosphorus abundance in organic manured fish ponds. AACL Bioflux 5(4):223-230.

Dasgupta, S.; Pandey, B.K.; Sarangi, N. and Mukhopadhyay, P. K. (2008). Evaluation of water productivity and fish yield in sewage-fed vis-a-vis fertilized based carp culture. Bioresource Technology 99(9):3499-3506.

Edwards, P.; Pacharaprakiti, C. and Yomjinda, M. (1994). An assessment of the role of buffalo manure for pond culture of tilapia.1.On-station experiment. Aquacult., 126 (1-2): 83-95.

Ekpenyong, K. (2000). Algal biomass and pigment diversity in typical tropical fish ponds. Tropical Ecology 41(1):89-94.

Eroldogan, O.T.; Kumlu, M.; Kiris, G.A. and Sezer, B. (2006). Compensatory growth response of Sparusawrata following different starvation and refeeding protocols. Aquaculture Nutrition, 12:203-210.

Jha, P.; Barat, S.and Nayak, C.R. (2008). Fish production, water quality and bacteriological parameters of Koi carp ponds under live-food and manure based management regimes. Zoological research, 2: 165-173.

Knosche, R.; Schreckenbach, K.; Pfeifer, M. and Weissenbach, H. (2000). Balances of phosphorus and nitrogen in carp ponds. Fisheries Manag. \& Eco. 7(1-2):15-22.

Sevilleja R.; Torres, J.; Sallows, J. and Little, D. (2001). Using animal waste in fish ponds. In: Integrated Agriculture-aquaculture. A prime.Halwart M., Gonsalves J., Preli M. (eds). FAO Fisheries Technical Paper 407, FAO, Rome (Italy).

Shaker, I.M; Mona, A.H. and Soliman, A. (2016). Environmental impacts of pond managements on water quality, plankton abundance and productions of tilapia and mullet in earthen ponds. Impress in Abbassa, Int., J. Aqua.

Shaker, I.M.; Rabie, G.H.; Ismaiel, A.A. and Mekawy, M.T. (2015). Impacts of Some Environmental Conditions on Water Quality and Some Heavy Metals in Water of Different Aquaculture Sites.Middle East Journal of Applied Sciences ISSN 20774613.Volume : 05 | Issue : 03 | July-Sept. Pages: 742-750.

Shaker, I.M.; Ibrahim, N.; Dawa, A. and Zakar, A. (2002). Effect of stocking density on water quality and mullet growth in earthen ponds at Sahl El-Teena- Senai- Egypt. The $6^{\text {th }}$ Vet. Med. Zagazig. Conf., 7-9 Sept. Hurghada, Egypt, pp.

Shaker, I.M; Abou Zeid, M.Y. and Batran, A. (2013). Effect of using periphyton substrate (bamboo stems) on water quality, phytoplankton, zooplankton, periphyton and growth performance for tilapia, mullet and catfish in earthen ponds. Abbassa, Int., J. Aqua.Vol. 6 (No 1): 108-139.

Shaker, I.M. (2008). Effect of using different types of organic manure (compost; chicken, Mycelium) and mineral fertilizer on water quality, plankton abundance and on growth performance of Oreochromis niloticus in earthen ponds. AbbassaInt .J. Aqua. 203-226. 
Shaker, I.M. and Abd El Aal, M.M. (2006).growth performance of fish reared under different densities in semi-intensive and extensive earthen ponds. Egypt. J. Aquat. Biol. \& Fish ., 10(4): 109-127.

Shaker, I.M.; Mona, A.H. and Mahmoud, A.A. (2009b). Effect of periphyton substrate on water quality and growth performance of Nile tilapia in earthen ponds. Abbassa International J. for Aqua., Special Issue for Global Fisheries \& Aqua. Res. Conf., Cairo International Convention Center, 24-26 October pp 741-763.

Shaker, I.M.; Agouz, M.H. and Mahmoud, A.A. (2009a). Environmental impacts of fish cages in Lake Manzalla and growth performance of different fish species. Egypt. J. Aquat. Biol. \& Fish., 13(4): 293- 308.

Shaker, I.M.; El-Nagdy, Z and Ibrahim, N.A. (2003). Effect of organic manure and artificial feeding on water quality and growth performance of Mullet in earthen ponds in Sahel El-Teen, Egypt.Scientific conf. of the Egyptian Aqua. Society, Fac, of Env.Agric, Sci. El-Arish, North Sina, Egypt, 13-15 Dec. 77-96.

Statistical Analysis System (SAS) (2000). SAS program ver.612, SAS istitutein corporation, cary, NC 27513 USA.

Stephen, P. (2010). Alkalinity in Aquaculture: Nuts and Bolts Hatchery International, 2425.Paraqua.com_wp_content_uploads_2012.pdf.

Wetzel, R.G. (1975). Limnology.W.B. Saunders Company, Philadelphia, PA.

Yang, Yi; Kwei, C.L. and Diana, J.S. (2003). Hybrid Catfish \{Clarias macrocephalus x C. gariepinus) and Nile tilapia (Oreochromis niloticus) culture in an integrated pen-cum pond system: growth performance and nutrient budgets.Aqua., 217: 395-408.

\section{ARABIC SUMMARY}

الآثار الاقتصادية لإدارة الأحواض على جودة المياه و نمو الأسماك في الإستزراع المختط

$$
\begin{aligned}
& \text { إبراهيم محمد شاكر ' ـ محمد يحى أبو زيد' ــ علم الدين فاروق أحمد' }
\end{aligned}
$$

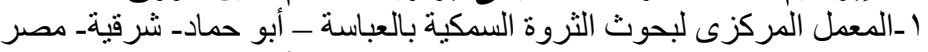

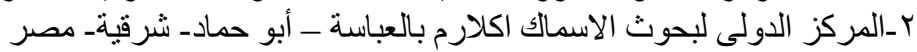

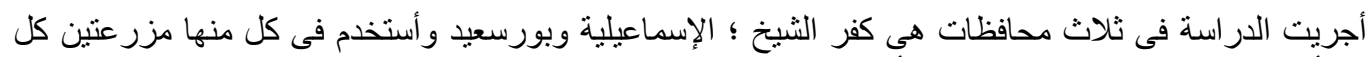

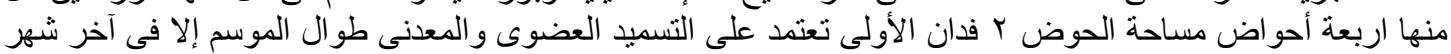

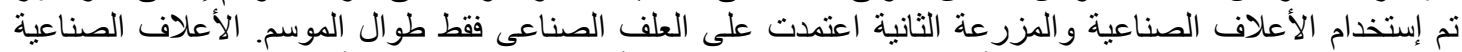

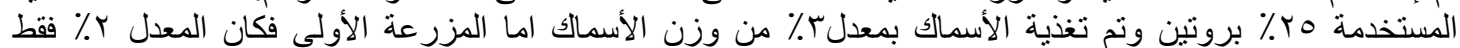

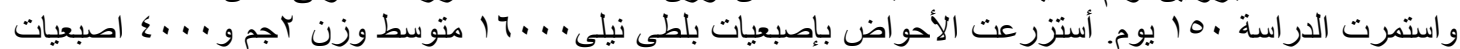

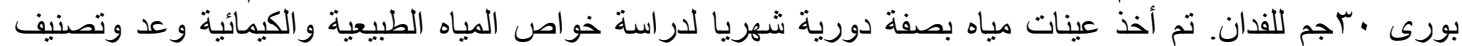

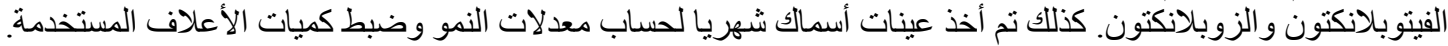

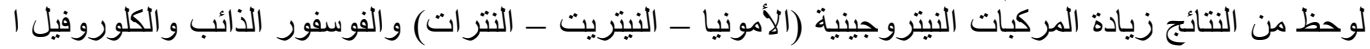

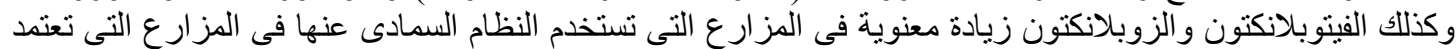

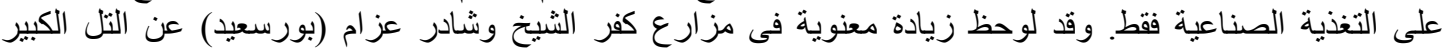

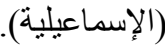

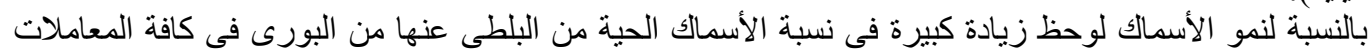

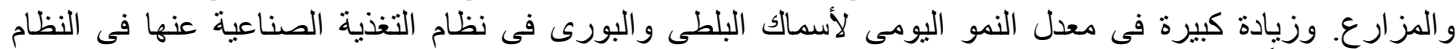

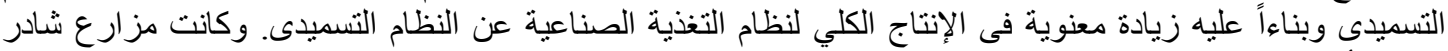

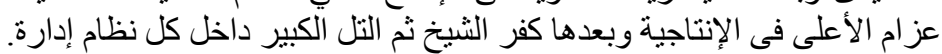

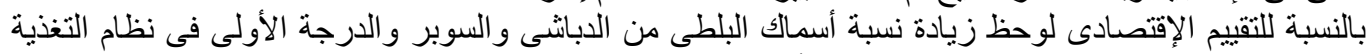

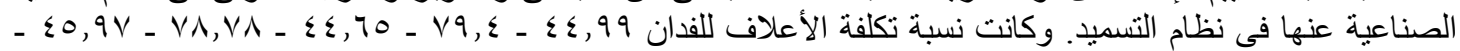

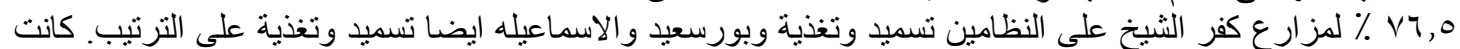

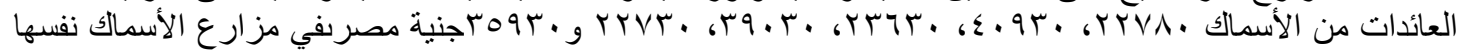

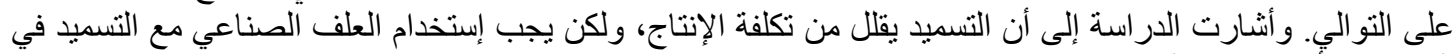

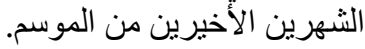

